Association for Information Systems AIS Electronic Library (AISeL)

Wirtschaftsinformatik Proceedings 2005

Wirtschaftsinformatik

February 2005

\title{
E-Collaboration: A Problem-Based Virtual Classroom Approach to International E-Business Qualification
}

Eric Schoop

Dresden University of Technology, Germany

Kay-Uwe Michel

Dresden University of Technology, Germany

Dalia Kriksciuniene

Vilnius University, Lithuania

Rasa Brundzaite

Vilnius University, Lithuania

Agnieszka Miluniec

Technical University of Szczecin, Poland

Follow this and additional works at: http://aisel.aisnet.org/wi2005

\section{Recommended Citation}

Schoop, Eric; Michel, Kay-Uwe; Kriksciuniene, Dalia; Brundzaite, Rasa; and Miluniec, Agnieszka, "E-Collaboration: A Problem-Based Virtual Classroom Approach to International E-Business Qualification" (2005). Wirtschaftsinformatik Proceedings 2005. 41.

http://aisel.aisnet.org/wi2005/41

This material is brought to you by the Wirtschaftsinformatik at AIS Electronic Library (AISeL). It has been accepted for inclusion in Wirtschaftsinformatik Proceedings 2005 by an authorized administrator of AIS Electronic Library (AISeL). For more information, please contact elibrary@aisnet.org. 
In: Ferstl, Otto K, u.a. (Hg) 2005. Wirtschaftsinformatik 2005: eEconomy, eGovernment, eSociety; 7. Internationale Tagung Wirtschaftsinformatik 2005. Heidelberg: Physica-Verlag

ISBN: 3-7908-1574-8

(C) Physica-Verlag Heidelberg 2005 


\title{
E-Collaboration: A Problem-Based Virtual Classroom Approach to International E-Business Qualification
}

\author{
Eric Schoop, Kay-Uwe Michel \\ Dresden University of Technology, Germany \\ Dalia Kriksciuniene, Rasa Brundzaite \\ Vilnius University, Lithuania \\ Agnieszka Miluniec \\ Technical University of Szczecin, Poland
}

Abstract: We present e-collaboration as an innovative e-learning concept, which provides three main potentials for e-business qualification. Collaboration in the virtual classroom develops the soft skills necessary for working in global virtual teams. Project experiences, based on authentic case studies, help students to transfer their academic knowledge to the e-business application level. Our problem-based collaborative framework invites for integrating university learners and company experts, thus forming a lifelong e-collaboration society. Our conclusions are based on empirical case study results of a tri-national virtual collaborative learning project, carried on in May 2004 by Dresden university of Technology (Germany), Szczecin University (Poland) and Vilnius University (Lithuania).

Keywords: Bologna Process, e-learning, problem-based learning, virtual collaborative learning, e-collaboration, case database, success factors

\section{Context}

In summer 2004 an international virtual classroom project was executed with students participating from three European countries (Germany, Lithuania, Poland), collaborating in mixed teams. This tri-national project was number eleven so far of a sequence of similar approaches, all following a certain, stepwise refined conceptual framework derived from scientific perception and intensive evaluation of the former projects' performances. Before we concentrate upon the actual project's analysis and evaluation, we first discuss the main contextual aspects influencing our approach, shortly summarize the specific conceptual framework for our 
virtual classroom projects (we call them $\mathrm{VCL}=$ virtual collaborative learning), and point out objectives and settings of the tri-national VCL project.

\subsection{Motivation}

Three main aspects motivated us to attempt a tri-national virtual classroom project, inspite of the resulting - expected - difficulties:

1. European challenge: On the European Union's roadmap “[...] to establish a more complete and far-reaching Europe, in particular building upon and strengthening its intellectual, cultural, social and scientific and technological dimensions" [Bolo03, p. 241], it is recognized that "[...] the ways in which knowledge and skills are developed and conveyed are changing. [...] More education will be delivered through the Internet, through transnational arrangements, through a combination of traditional and non-traditional learning, and the recognition of various kinds of prior learning, including work-based and technology-based learning, must be improved." [Berg03, p. 176]. The "Bologna Process" towards the European Higher Education Area is reflected in actual EU calls for proposals, for example the eLearning Call for Proposals DG EAC/26/04, closed May 28 $8^{\text {th }}, 2004$ [EC04]. Its subject "Virtual Campuses" emphasizes the utilization of Internet-based communication and collaboration, based upon transnational arrangements. Bridging borders having separated countries (and political systems) for centuries by the use of Internet, and integrating students in tight transnational environments, intercultural differences in learning, communicating and collaborating come to the fore, as for example exemplified in extreme border line situations (Nepal) in [Puls03].

2. Pedagogical perspective: The current psychological and pedagogical understanding of learning processes is influenced by the constructivist perspective as well as by modern instructional approaches. Both perspectives have in common, that "[...] learning is seen as an active, socially transmitted and situated process of the individual construction of knowledge and ability, desire and feeling" [Klau ${ }^{+}$4, p. 7]. Complex learning environments consist of authentic cases, thus enabling social co-operation, individualization, and differentiation by the combination of individual-, partner- and group-work. This problembased, situated learning [ $\left.\mathrm{Mand}^{+} 02\right]$ brings students to an active an co-operative form of learning - i. e. independent problem solving by the use of authentic and complex cases. The modern information infrastructure supports these objectives by providing synchronous and asynchronous communication and network-based co-operation, various presentation- and work-mediums, tutorial components, feedback-systems and the open accessibility of the Internet [Klau ${ }^{+} 04$, pp. 9]. If both teachers and learners are aware of these possibilities and if they accept their utilization often being connected with an increasing workload on both sides, attractive advantages can be achieved in comparison 
to traditional, locally bounded classroom teaching: e. g. flexibility of individual and productivity of shared group work, support of collaborative skills, accessibility of remote participants and knowledge and familiarization with intercultural aspects [BaSc02a; $\mathrm{BaSc} 04$ p. 74].

3. E-business application: What is the link between e-learning and e-business, besides both paradigms relying on Internet technologies? Thanks to innovative information infrastructure, the automation of inter-organizational and international business and administrative processes and the ubiquitious accessibility of partners in global networks become reality. The migration of traditional business processes to e-business goes hand in hand with opening organizations and its' members to global markets. In networked organizations the demand for the employees' competence in computer supported cooperative work technical performance, foreign language skills and intercultural awareness - is increasing. The correlation between collaborative virtual communities and collaborative business for example is discussed for collaborative engineering in [Gron ${ }^{+} 03$ ]. Additionally we can detect not only e-business demands for new kinds of communication, collaboration and learning, but it was also observed already years ago that e-learning can benefit strongly from e-business [BoLa97]. Consequently, e-business is reference object of several e-learning environments developed in the past years to provide online materials for university and vocational education (e. g. the IMPULS ${ }^{\mathrm{EC}}$ research project ${ }^{1}$ giving the background for our preliminary work on virtual classroom learning).

\subsection{Virtual Collaborative Learning - a conceptual framework}

How to organize and to operate (also internationally applicable) virtual collaborative learning on authentic e-business cases? We recognized that it is not sufficient just to provide collaborative information infrastructure for eLearning communities, offering readings for download, and synchronous and asynchronous communication platforms. If we want to achieve at least some of the above discussed collaborative objectives efficiently, we need to take a more systematic and controlled approach.

In [BaSc04] the findings of 3 years of empirical studies of deliberately varied settings of virtual classroom projects are summarized. Based on this cognition, supported by numerous conclusions in scientific literature, we developed a conceptual framework for planning, designing, preparing, operating and evaluating virtual classroom projects. Characteristics of our VCL approach are

1 The IMPULS ${ }^{\mathrm{EC}}$ project lasted from 2001-2004, producing about 200 learner's hours of multimedia content on e-business topics relating to a complex model case, thus providing for situated, individual self paced online learning and for intensely tutored virtual collaborative learning. It was funded by the German ministry for Education (BMBF), no. 01 NM 067 D; for details see http://www.impuls-ec.de 
- Separation of collaborative projects into 5 phases with the teacher's decisions in each phase influencing later setttings,

- Formation of heterogeneous, self organized groups with 4 to 6 members collaborating on complex problems which have open solutions,

- Assignments embedded into an authentic cover story modelled as business case, the students to take over specific roles and achieve given tasks as collaborating teams,

- Evaluation of students based on a mixture of group achievement, individual communicative performance, role fulfillment and intra-group reciprocative assessment,

- Advance information of both tutors and students in forms of detailled guidelines, informing about the case, the roles, the tasks and the assessment criteria, and giving hints about potential drawbacks, conflicts and possible solutions,

- Application of intense tutoring in forms of coaching, giving feed-back and motivating, not influencing or teaching task solutions [BaSc04, pp. 75-85].

VCL projects following our framework typically last about 3 to 4 weeks, demand a high weekly workload from students (on the average $1 \mathrm{~h}$ per student and day for each team member; about $1 \mathrm{~h}$ per student and week for the coaching and assessing tutor), and produce more than 1.000 postings with significant content.

\subsection{Tri-national VCL project: settings and objectives}

In accordance with the Bologna Process' objectives, our motivation was to transfer our mainly national (German) experience in VCL projects - with positive acceptance from students in spite of the high workload, and by the majority very effective group performance demonstrating the achievement of collaborative pedagogical objectives - into an European context. Based upon Sokrates/Erasmus staff mobility funding, we started with a

- preliminary 2-weeks national VCL project in Kaunas, Lithuania, to prepare for

- the succeeding tri-national VCL project mainly discussed in this paper.

Objectives of the preliminary project were to conduct a VCL project in English language for the first time, to train the Lithuanian students in virtual collaboration, to utilize their domain expertise to describe in detail authentic business processes, relating to existing organizations, and to model these in forms of e-business cases in HTML. ${ }^{2}$ The 2 weeks of virtual collaboration in 4 groups with 23 students in

2 The resulting 4 model cases can be accessed at http://www.mobil-eb.de. They are arranged together with a detailed e-business process model, also in HTML, in German language (result of a former students' project in Dresden). The business areas 
their first year of master program in business informatics were framed by an introductory on-site lecture about e-business context and about the conceptual framework of the VCL project, by an extensive on-site Kick-Off meeting and a final onsite presentation of the groups' results. The collaborative platform hosted at Dresden University of Technology at Dresden University provided three collaboration channels: discussion forum (team work, asynchronous), conference (team work, synchronous), instant messenger (person to person synchronous).

The preliminary project encountered strong acceptance by students and local tutors in spite of the high additional workload, and produced astonishing results. These motivated for the succeeding tri-national VCL project. Here the settings differed in several aspects:

- The authentic business cases for the groups' collaboration already existed from the preliminary work and should be enhanced,

- The model case related tasks concentrated upon a new subject: business and IT strategy planning instead of describing authentic, existing business processes,

- The students' competences were enhanced by integration of additional group members from Poland and from Germany, resulting in mixed tri-national teams; at the project's start the additional members were not familiar with the business case models,

- Caused by the tri-national group settings, the group members did not know each other personally and did not have the chance for a face-to-face meeting while the project lasted; therefore the time schedule was enhanced to 3 weeks, the first week providing time for a virtual kick-off and an anticipated slower start of collaboration on easier entrance tasks.

Main objective of the succeeding tri-national VCL project was to analyze the effects of the modifications of settings, concentrating primarily upon the more complex tasks and upon the greater heterogenity of the groups' structure and competences. Our hypothesis was that in spite of the expected difficulties in intercultural collaboration,

- the demand for special competences ${ }^{3}$ not available locally, and

- the necessitiy to use the Internet for communication between group members

modelled are production (clothing sewing), retailing (bookstore), customer service (banking), and government (local municipality). All organizations are operating in Lithuania.

3 Lithuanian members' competence $=$ domain experts, Polish members' competence $=$ having experience in strategic success factors' analysis and in IT strategy planning, German competence $=$ having the most experience in self organized group learning and having access to the basic informations available only in German language (former projects' evaluation, extended guidelines, readings on collaborative learning) 
would develop a highly reciprocative dependency between the members inside each group and therefore would finally result in an intense collaboration and strong group performance.

\section{Projects' analysis}

When starting the project, we knew already about the significant influence of the situative context both on the learning processes and on the final results of the collaboration. The orientation at authentic business cases intensifies the discussion in the VCL forum and challenges to evaluate the team decisions according to their potential usability in the real world context. For the deeper understanding of this process the 2 succeeding VCL projects were analyzed, focussing on the following interest areas:

- Advanced skill-building capabilities as a result of group collaboration, and shortcomings and derived strategic success factors for virtual teamwork,

- Identifyable patterns of e-collaboration processes, requirements for describing situative context supporting problem-based learning and for facilitating further reuse and extension of the case database.

\subsection{Analysis based upon projects' data}

This analysis and evaluation focuses upon the comparison of statistical data of both VCL projects about the communication processes in context with the problems and solutions behind. Most data were derived manually from the collaboration platform's log files and protocols.

\subsubsection{Preliminary national VCL project}

The emerging demands of global e-business processes for employees' skills can be summarized into 2 categories: knowledge creation and sharing on the one hand, and ill-defined problems solving (see table 1). Those categories were objectives of our preliminary VCL project and center of our analysis. 


\begin{tabular}{|l|l|}
\hline Category & Skills \\
\hline $\begin{array}{l}\text { Knowledge creat- } \\
\text { ing and sharing }\end{array}$ & $\begin{array}{l}\text { Capabilities to plan, supervise and judge own learning processes } \\
\text { [Seuf00] } \\
\text { Practicing empathy, appreciating the other person's point of view } \\
\text { [Nuld99] } \\
\text { Collaborating productively in groups or teams [Nuld99] } \\
\text { Individual capability to take part in organizational learning processes } \\
\text { [BaSc04, p. 67, 70] }\end{array}$ \\
\hline Ill-defined prob- \\
lem solving & $\begin{array}{l}\text { Ability to solve problems by using domain-specific expertise. This } \\
\text { requires reproductive skills as well as productive skills, necessary for } \\
\text { acting in new and ill defined problem areas [Kess00] } \\
\text { Capability for collaborative problem solving from a multiple per- } \\
\text { spective point of view [BaSc04, pp. 73] } \\
\text { Appropriate remediation undertaking by indicating need of addi- } \\
\text { tional self-directed learning [Nuld99] }\end{array}$ \\
\hline
\end{tabular}

Table 1: Skills of knowledge workers

\subsubsection{Data collection}

The participants of the preliminary VCL project formed four teams. The knowledge sharing process in the virtual environment was organized inside teams according to the accepted roles of leader, researcher, critics, programmer and report writer. Each team had at least one "domain expert" - a group member with expertise in the authentic real world enterprise to be modelled. The main source of data for the analysis was a database formed of messages, posted into the asynchronous discussion board. The total amount of messages posted during the preliminary project was 1108. 989 messages were selected for detailed analysis, 119 messages were excluded as not relevant (trial entrance, tutor's remarks).

\subsubsection{Data analysis and evaluation}

The groups' results in forms of common documents, and the processes, leading to ill-defined problem identification and solving, were both evaluated. The final solutions of the teamwork were evaluated by ranking from best result downwards: $3^{\text {rd }}$, $4^{\text {th }}, 2^{\text {nd }}, 1^{\text {st }}$ teams. The problem solving processes of the teams were reflected by analysis of the message distribution along different categories:

- Organizational (including planning, controlling, motivating),

- Discussion (question, answer, agreement, idea presenting), 
- Adding content (presenting research information, presenting work share adding to final result).

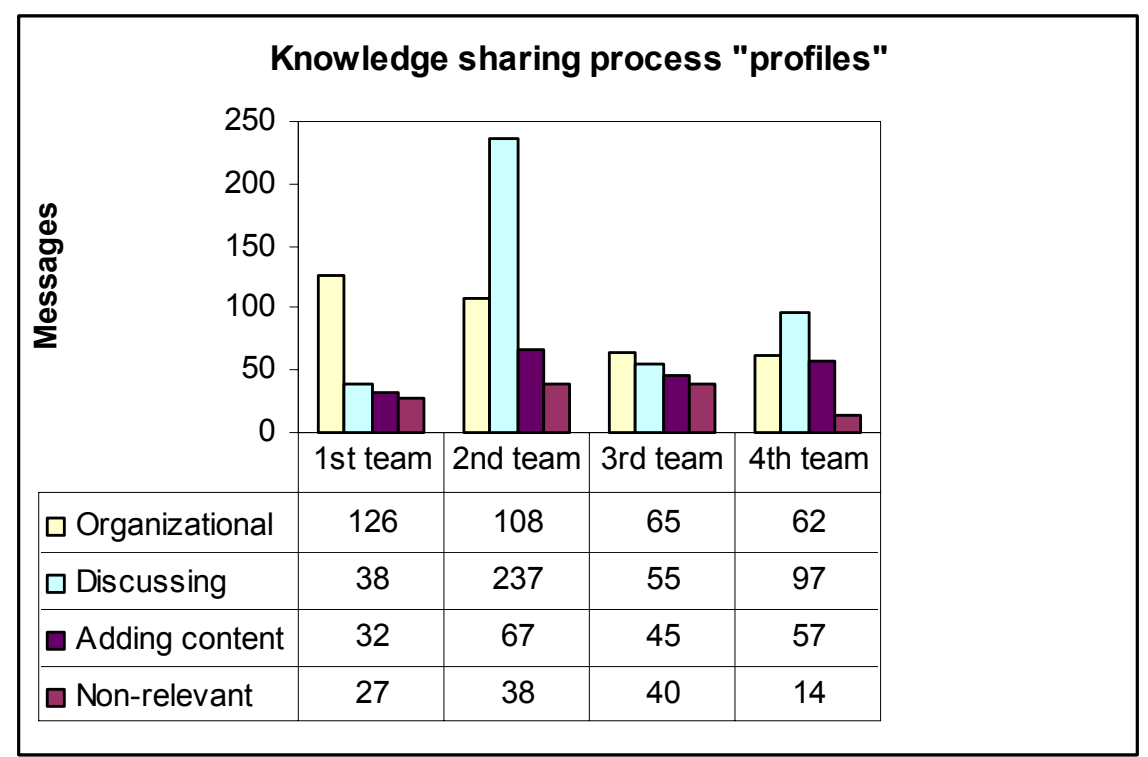

Figure 1: Message distribution in knowledge sharing process

The "profiles" of the categorized messages of collaboration processes were generated on a daily basis. The final "profile" of whole project period is presented in figure 1. Organizational messages were the most frequent in $1^{\text {st }}$ team, while their discussion level was comparatively low (correspondingly $64 \%$ and $19 \%$ ), making contrast to team $2^{\text {nd }}(26 \%$ and $58 \%)$. The teams 3 and 4 , ranked best by final results, had a similar share of messages in all 3 categories, slightly more in the "adding content" part. According to the ranking of final results, it could be noticed that a proportional ratio among the three main categories could lead to better result of e-collaboration.

Analysis of collaboration "profile" - the distribution of messages along categories - can be used by students and tutors for further analysis of their influence factors upon the final result. The analysis on a daily basis can provide useful information about the quality of team discussion and about the relevance of individual inputs for reaching important milestones of the task. That differs a lot from traditional subject-oriented learning, where achieved knowledge is checked in forms of tests, rather not giving space for developing the skills being the objectives of VCL.

The knowledge integration skills were mainly developed in collaboratively producing the final results of the project. They included knowledge of investigating the real business case, analysis of business strategy, value chain, supply chain 
processes, e-process scenario modeling, system modeling and HTML programming. The business cases were presented in freely composed forms as HTML sites, describing the development of particular business processes to future ebusiness scenarios.

To summarize the preliminary project, we can conclude that collaboration in the virtual classroom indeed improves the soft skills necessary for working in global virtual teams. Project experiences, based on authentic case studies, help students to transfer their academic knowledge to the e-business application level.

\subsubsection{Succeeding tri-national VCL project}

The succeeding tri-national VCL project relied upon the re-use and further development of the 4 business cases collaboratively created during the first project. The new task of a stepwise development of an IT strategy required some changes of the project's settings and the collaboration scheme, as presented by the UML class diagram (figure 2):

- The domain expertise inside each team was now supported by the re-used case.

- Additional team members allowed for knowledge specialization within each team in the fields of business (domain) expertise, information management expertise, and collaboration expertise.

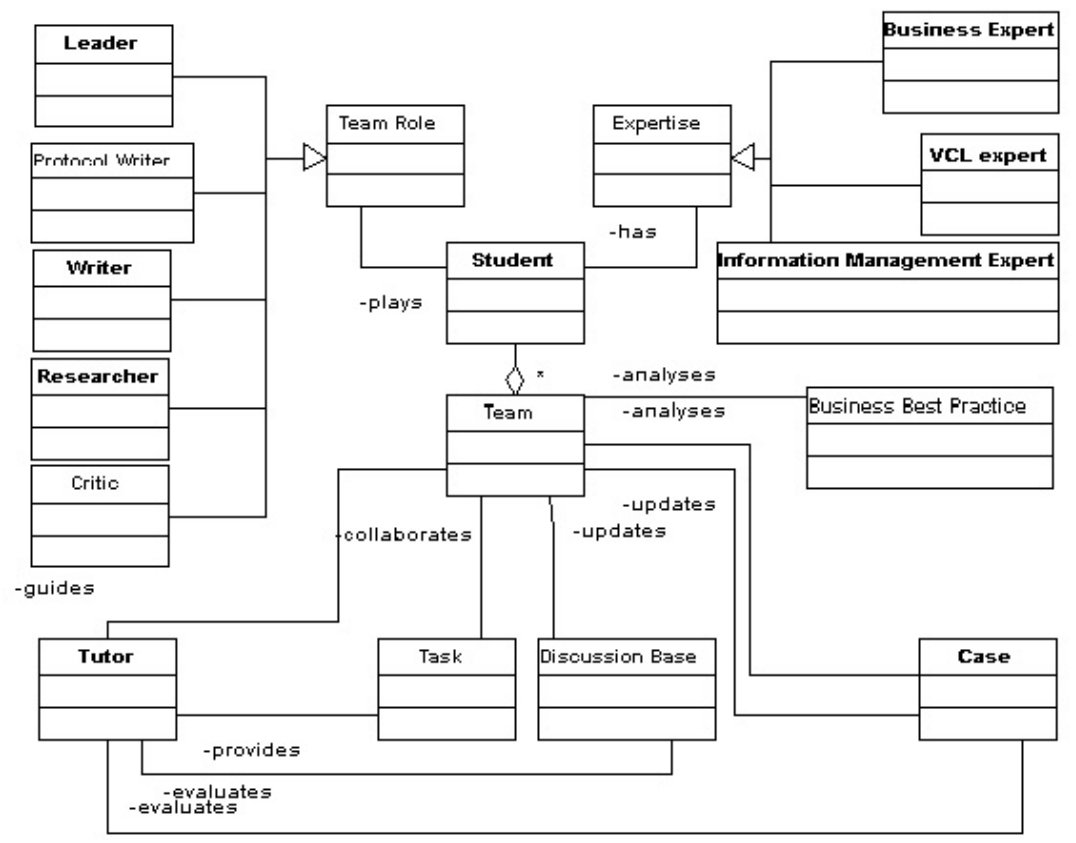

Figure 2. The UML class diagram of the 2 nd project settings 
The initial analysis revealed, that the potential contribution of using the existing cases for solving new business tasks was limited, mainly because of their freely composed monolithic structures and the selective focuses of the HTML models. Though it is ackknowledged, that the context of the case is generally the most important factor in the case based reasoning, here the context was only in parts accessible, the deeper knowledge "behind" staying fragmentized inside different discussion messages in the asynchronous forum of the preliminary project, which was familiar only to it's (Lithuanian) participants. As result a lot of misunderstandings and necessary, time-consuming explanations of the "stories behind" happened.

\subsubsection{Data collection}

Four international teams were formed, each consisting of 1 new German and 1 new Polish student and 2 (or more, alternately changing) Lithuanian students already familiar with the cases from the preliminary project, sharing roles and expertise according to figure 2. The project database consisted of 635 messages posted in the discussion forum and 5994 contributions in the virtual conference.

Several organizational and technical improvements derived from the evaluation of the preliminary project were introduced, which modified the data collection procedure:

1. In contrast to unlimited postings according to topic-related threads in the first project, the messages in the asynchronous discussion forum were now categorized by the students in orientation at appointed meta-threads of "solution articles", "actual progress", "coordination" and "off topics". That helped to improve knowledge structuring and understanding for students, and to easier follow and evaluate the discussion flow by the tutors. Unfortunately, this semantical structuring could not be applied to the synchronous communication, which was very intensive during the tri-national project, possibly supplementing for the lack of direct communication and covering up for interpretational problems concerning the business case behind.

2. The structure of the collaboration process was improved by adding milestones for gaining intermediate results of teamwork. It helped to manage the complexity of the tasks, stress the importance of intermediate stages of problem solving and to analyze the discussion database from the perspective of stepwise solution building.

The case creation and re-use process is further illustrated by the resulting data of two target teams: "government" and "bookstore". Only contributions containing substantial discussion and contents in the forum and in the conference were analyzed: the bookstore team had posted 601 messages, the government team 679 messages of these categories. 


\subsubsection{Data analysis and evaluation}

The analysis of the first question - the process of case creation, re-using and augmenting it during the virtual collaboration - was made in two steps:

1. comparing the resulting solutions (cases) provided by teams in both preliminary and succeeding projects and

2. relating parts of the discussion processes as context to structural parts of the cases behind.

The solutions presented by both teams were splitted to structural components, according to the assumed general case structure: description of business area and environment, organizational structure and geographical location of departments, analysis of value chain components business goals and processes.

The structured views upon the cases, with the number of discussing and content bearing messages, related to the case topics, are presented in figure 3 (government) and figure 4 (bookstore). Case 1 and 2 components are marked as darkers areas, the messages were allocated on daily basis for the preliminary project and on milestone basis for the succeeding tri-national VCL project.

The case re-use by the teams was analyzed by relating messages to structural parts of the cases. Problem identification and solution creation topics were particularly analyzed only in the preliminary project. But for reaching milestones 1 and 2, both teams came back to topics of the first case and made extended discussion on these problems, by adding new content to their cases, as to the solutions, and to context (see business processes, area and environment components, figures 3 and 4).

\begin{tabular}{|c|c|c|c|c|c|c|c|c|c|c|c|c|c|c|}
\hline GOVERNMENT TEAM & \multicolumn{9}{|c|}{ PROJECT 1} & \multicolumn{3}{|c|}{ PROJECT 2} & \multirow{2}{*}{$\begin{array}{c}\text { Case } \\
1 \\
\end{array}$} & \multirow{2}{*}{\begin{tabular}{|c} 
Case \\
2
\end{tabular}} \\
\hline & 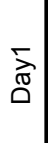 & 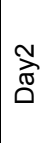 & 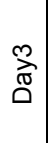 & 莞 & 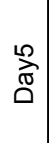 & $\stackrel{0}{\stackrel{\sigma}{\sigma}}$ & 希 & 㐫 & D & 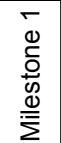 & 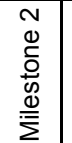 & 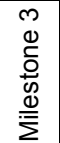 & & \\
\hline Business area & 1 & 6 & & & & & & & & & & & & \\
\hline Business environment & 2 & 4 & & 2 & & 5 & 2 & 1 & & 11 & & & & Z \\
\hline Organizational structure & 1 & 2 & & & & & & & & & & & & \\
\hline \multicolumn{15}{|l|}{ Location } \\
\hline Value chain components & & 3 & & & 1 & & & 2 & & & & & 6 & DOI \\
\hline Processes & & $\overline{1}$ & & & & $\overline{1}$ & 14 & $\overline{9}$ & $\overline{1}$ & 9 & & & & 100 \\
\hline Business goals & & & & & & & & & & 267 & 13 & & & \\
\hline Problem 1 & 2 & 8 & 2 & $\overline{1}$ & 4 & 1 & 2 & & & & & & WDID & \\
\hline Solution 1(e-business) & & & 5 & & & 1 & 4 & $\overline{7}$ & $\overline{9}$ & & & & 01 & \\
\hline Problem 2 (SF) & & & & & & & & & & & 197 & 1 & & $\mathbb{Z 1 / 1}$ \\
\hline Solution 2 (IT strategy) & & & & & & & & & & & 3 & 178 & & \\
\hline & & & & & & & & & & & & & & \\
\hline
\end{tabular}

Figure 3. Case component creation process in government team 


\begin{tabular}{|c|c|c|c|c|c|c|c|c|c|c|c|c|c|c|}
\hline \multirow{2}{*}{$\begin{array}{l}\text { BOOKSTORE TEAM } \\
\text { Collaboration process }\end{array}$} & \multicolumn{9}{|c|}{ PROJECT 1} & \multicolumn{3}{|c|}{ PROJECT 2} & \multirow{2}{*}{$\begin{array}{c}\text { Case } \\
1\end{array}$} & \multirow{2}{*}{\begin{tabular}{|c|} 
Case \\
2 \\
\end{tabular}} \\
\hline & 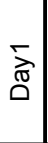 & 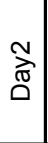 & 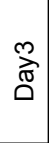 & 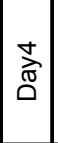 & 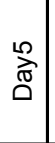 & $\stackrel{\varphi}{\stackrel{0}{\pi}}$ & 㐫 & $\stackrel{\infty}{\underset{\pi}{\sigma}}$ & त) & $\begin{array}{l}\bar{d} \\
\stackrel{0}{0} \\
\frac{0}{\infty} \\
\frac{\Phi}{\Sigma}\end{array}$ & 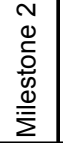 & 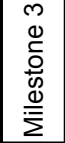 & & \\
\hline Business area & & & & & & & & & 1 & 20 & & & & \\
\hline Business environment & 1 & & & & & & 5 & 6 & & 2 & & & & \\
\hline Organizational structure & 5 & & & & & 1 & & 2 & & & & & & \\
\hline Location & & & & & & & & 7 & & & & & & \\
\hline Value chain components & 1 & & 11 & & & & & & 5 & & & & & \\
\hline Processes & 8 & & & 1 & & 1 & 1 & 1 & 3 & 24 & & & & \\
\hline Business goals & & & & & & & & & & 112 & 23 & & & \\
\hline Problem 1 & 1 & 3 & 23 & 3 & & & & 1 & 3 & & & & 70 & \\
\hline Solution 1 (e-business) & 1 & 4 & 2 & 2 & 4 & 1 & 13 & 5 & 14 & & & & 74 & \\
\hline Problem 2 (SF) & & & & & & & & & & & 230 & & & \\
\hline Solution 2 (IT strategy) & & & & & & & & & & 6 & & 184 & & \\
\hline
\end{tabular}

Figure 4. Case component creation process in bookstore team

Our conclusion: authentic case bases, to be analyzed in virtual collaboration should be arranged in three main forms for a successful re-use:

1. complete solution, presented as a resulting case of virtual collaboration,

2. separately structured case components, related to different topics of business analysis, and

3. message context database, categorized according to the related case components.

The second question of research, indicating needs of teams for academic and business knowledge supply in solving authentic business problems, is analyzed by tracking the collaboration processes on daily or milestone basis (figures 3 and 4). Numerous messages along all periods of teamwork show intensive everyday discussions on problem identification and solution in both teams of bookstore and government. This constant process is supported by discussing different business topics, based on academic knowledge and business domain expertise (see messages on different case topics in figures 3 and 4). Some topics, such as organizational structure, were discussed only in the beginning of the project, but knowledge of value chain and processes needed constant in-depth consulting.

From the one side, this demonstrates a certain viability of case based learning, by the possibility to extend case materials and re-use it for solving different tasks. On the other side, that can be interpreted also as an expression of the teams' demands for more extensive support by consultants from business organizations and by academical experts (i. e. tutors).

Our VLC projects' experiences encourage us to further reveal its' potentials for the development of knowledge sharing, problem based and case based learning 
skills. It also challenges to find solutions for an improved VCL environment and conceptual VCL framework following the results of our research.

\subsection{Analysis based upon strategic success factors for VCL}

Besides evaluating statistical data, we additionally wanted to take into account the participants' personal opinions to find clues for further improvement of our conceptual VCL framework. This was the more interesting, as our students just had been confronted with the application of the strategical success factors's analysis in week 2 of the tri-national project, to provide information for the $3^{\text {rd }}$ week's derivation of their case-related IT strategy.

The original method was developed by Alloway to support strategic IT-planning [Hein02, p. 382]. To achieve meaningful results in the VCL context, it was necessary to modify the method to our context. We substituted the field of information infrastructure by VCL and adapted the potential success factors based on our experiences with former VCL projects. As the final results of our analysis demonstrate, our respondents confirmed our pre-selected factors. Their answers prove the applicability of the strategic success factors' analysis to identify the critical success factors, calling for necessary action to improve the conceptual VCL framework. These critical factors demonstrate the largest difference of suggested priority and perceived fulfillment in the concrete VCL project.

\subsubsection{Strategic success factors for Virtual Collaborative Learning}

A: Organizational Factors. How did the project's organizational aspects influence your team's success?

- Goal achievement

- Understandability of the tasks

- Time schedule compared to the task level

- Importance of the tutors' activities

- Posting of pre-start documents

B: Reciprocative evaluation between members. How did the group awareness influence collaboration and personal motivation within the team?

- Personal role performance

- Personal identification with the group

- Team spirit

- Identification of the other team members with the group 
- Satisfaction inside the group

- Working discipline

- Time management inside the VCL

- External influence upon the personal workload

C: Mutual knowledge. Did heterogenity influence the team's success?

- Complementary competences of the team members

- Language Skills

- Knowledge of technical terminology

- Domain competence

D: Communication structure and channels. How did you use the alternative communication tools?

- Synchronous communication

- Asynchronous communication

- Structure of postings

- Accessibility of group members

- Discipline of communication (milestones, threads)

E: Information Infrastructure. How strong did the technical basis influence your team work?

- System's usability

- System's navigation

- System's accessibility

\subsubsection{Applying the method}

\subsubsection{Data collection}

A few days after finishing the VCL project, a questionnaire was sent to all students, with 23 responses. Everybody was asked to evaluate the priority ${ }^{4}$ and the fulfillment $^{5}$ of each single success factor, as described above. Additionally two different views were evaluated: the tutors' replies, representing the VCL-staff, and the students' replies, representing the VCL-customers. As data were collected:

Priority refers to the importance of the specific success factor: how should it be?

Fulfillment describes the concrete achievement of the specific success factor: how was it done? 
1. Priority comparison for each success factor: tutors vs. students, tolerance 0.75 ;

2. Fulfillment comparison for each success factor: tutors vs. students, t. 0.75;

3. Strategic portfolio based upon priority and fulfillment: all replies, each view weighed by 0.5 , making it independent from the absolute number of replies;

4. Summarizing evaluation: all replies, average of all factors, giving as result for each participant one success value on a scale from 1 (failed) to 7 (excellent).

The commonly used calculation scheme is given here:

$$
S(T)=\frac{\sum_{K=1}^{25} P(K, T) * F(K, T)}{\sum_{K=1}^{25} P(K, T)}
$$

$\mathrm{S}(\mathrm{T}) \quad \ldots$ success value for interviewee $\mathrm{T}$

$\mathrm{P}(\mathrm{K}, \mathrm{T}) \quad$... priority value of success factor $\mathrm{K}$ and interviewee $\mathrm{T}$

$\mathrm{F}(\mathrm{K}, \mathrm{T}) \quad \ldots$ fulfillment value of success factor $\mathrm{K}$ and interviewee $\mathrm{T}$

\subsubsection{Data analysis and evaluation}

The interviewees were questionned individually, to avoid peer opinions. The tutors estimated the factors working discipline, identification of other team members with the group, posting of pre-start documents and goal achievement as most important. On the contrary, the students considered external influence upon the personal workload, domain competence, language skills and synchronous communication as the most important success factors for VCL projects (figure 5).

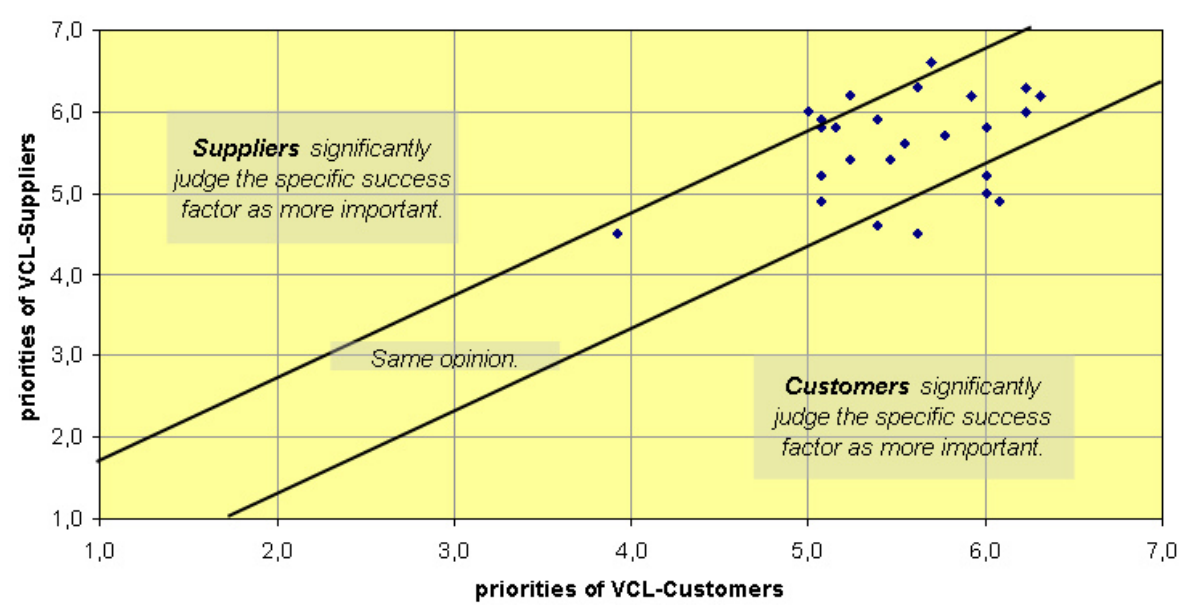

Figure 5: Priority comparison of VCL-suppliers (tutors) and -customers (students) 
Comparing the fulfillment of the factors in the tri-national VCL project, we detect as difference, that the tutors believed the factor system's accessibility to be excellent, while the students ranked first goal achievement and language skills.

The priority-fulfillment portfolio visualizes the allocation of the success factors to the key sectors ( $\mathbf{o k}=$ balance on sub-average level, success $=$ balance on aboveaverage level, waste $=$ bias to fulfillment, killer $=$ bias to priority). Waste factors (in our analysis synchronous communication and knowledge of technical terminology) should be weakened next time, to concentrate upon the improvement of the killer factors accessibility of group members, goal achievement, team spirit and understandability of the tasks (figure 6).

Regarding the average satisfaction of the students, most chose good or excellent to decribe their emotional cognition of the success of the tri-national VCL project.

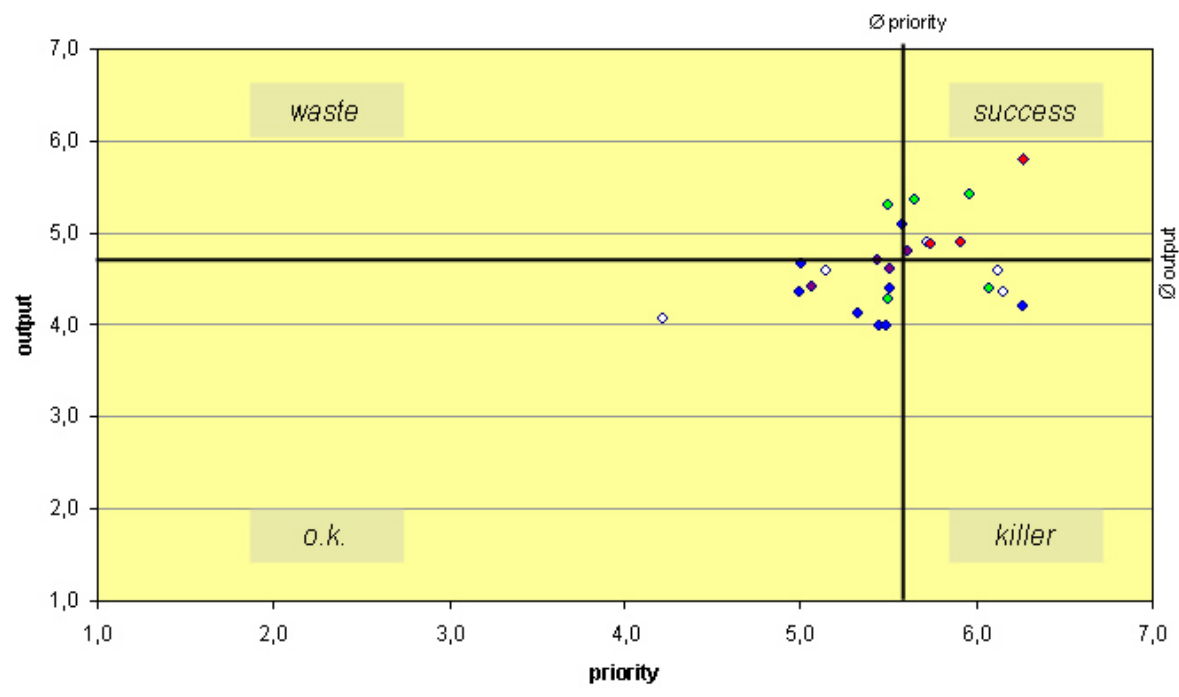

Figure 6: Priority-fulfillment (output) portfolio

\section{Conclusions}

The two succeeding VCL projects both had positive effects on the development of skills in the virtual environment and substantiating e-collaboration as a potential advanced learning scheme. Further directions of using this learning method should provide solutions to detected shortcomings revealed by our research. Three main directions for improvements of project settings are discussed, closing this paper. 


\section{Ensure re-usability of the case study by creating a structured case data base}

Our conclusion is supported by theoretical findings of knowledge management and preserving organizational memory. The main barrier to effective organizational memory is that documents are not preserved together with their context the very thing that allows them to be useful in the future, when the context has changed. As notions of organizational memory are mostly artefact-oriented, they focus on preserving, organizing, indexing, and retrieving only the formal knowledge, as it is stored in documents and databases [Conk96]. The nature of informal, contextual knowledge is difficult to register. Here the virtual environment of VCL projects could be beneficial, as teams communicate exclusively in a computerized environment and thus the generated contextual knowledge can be preserved.

For the better re-use of such knowledge, it must be structured in an appropriate manner. We suggest the basic structure of the context database consisting of three components, conforming to our research findings:

1. Result DB, consisting of solutions of business problems,

2. Case DB, consisting of structural components of the case, which could be used and enriched by succeeding problem-solving phases of virtual teamwork, and

3. Context DB, consisting of a better categorized message database.

The content of context DB and case DB could be accessible via a virtual hypertext navigation layer, developed using the topic maps technology. The accessibility of the databases' content should be further supported by advanced search and filtering tools, resulting in a successful re-use as a kind of project memory and business case repository.

\section{Activate engagement and consulting of learners in exploring real business situations and deepening their academic knowledge}

Case based learning provides more authenticity than other problem-based learning methods; nevertheless, they cannot fully provide the view of real business operations, which is obvious to organizational employees. There are several widely accepted options to integrate authentic business knowledge into learning processes, such as narrative cases prepared for academic use [Klau ${ }^{+} 04$, pp. 16-19], students' internship or regular meetings with business representatives. General knowledge of "best practices" could also be a valuable add-on to academic knowledge.

Using narrative cases or sporadic meetings with business partners gives only limited and non-extendable information for solving unstructured problem based tasks. We suggest a regularly partnership (community of practice), being tightly integrated into the virtual learning environment, adding authenticity to mixed practice-academic teams of VCL learners, jointly solving real business problems formulated by practical business experts, introducing modern academic methods into 
companies' decision making and having practitioners coach the students' approach to real world problems and their most efficient solution.

\section{Increase intelligent support for students and tutors by an advanced virtual collaboration environment}

The demand and complexity of tutorial team guidance were increased by several restrictions of the tri-national VCL project: team members were not acquainted to each other before, there was no possibility for them to meet face-to-face, there was no on-site kick-off meeting. Communication in English, foreign language to every participant, caused further obstacles for non-biased knowledge sharing and understanding. These conditions were very similar to ,authentic“ virtual team collaboration and created both difficulties and challenges to our tri-national teams.

A number of our analytical results of statistical data can be derived parallel to the VCL project developing. An early feedback to the students would inspire reflectiveness inside the teams, cause faster re-adjustment and could thus improve collaborative quality. But currently most evaluations on the tutors' side are done manually, too time-consuming for short-time feedback. First proposals for intelligent system support of tutors in VCL projects in forms of computerized content analysis can be found in [BaSc02b]. To ease communicative and collaborative problems on the students' side by the means of active advisory tools, we plan to refer to intelligent agent technology for e-learning, as suggested in [Payr03].

So, what are finally the potentials of e-collaboration for international e-business qualification? E-learning relying on social interaction and co-operation blends into e-collaboration. If e-learning successfully regards the demands for authentic cases in forms of situated (workgroup) learning, the difference to collaborative work on the job gradually disappears. Therefore we call methodical virtual classroom learning based upon our VCL conceptual framework e-collaboration. As our findings demonstrate, e-collaboration bears the following potentials:

1. Active collaboration in the international virtual classroom develops skills necessary for working in global virtual e-business teams: technical application and domain competence, CSCW competence, and intercultural awareness.

2. Situative context in forms of project tasks, based on authentic case studies, helps students to transfer their abstract academic knowledge to the e-business application level, thus avoiding the problem of inert knowledge.

3. An advanced problem-based collaborative framework could finally integrate university students and practical business experts to form a basic learning circle consisting of (internationally and interdisciplinary) mixed teams, tutors and advanced information infrastructure, resulting preferably in a lifelong $e$ collaboration society. 


\section{References}

[BaSc02a] Balázs, I.; Schoop, E.: Arguments for Building Learning Communities in Higher Education - First Results of an Empirical Research. In NETWORKED LEARNING IN A GLOBAL ENVIRONMENT. Challenges and Solutions for Virtual Education. Technical University of Berlin, Germany: Proceedings-CD by ICSC Academic Press, Canada/The Netherlands, 2002.

[BaSc02b] Balázs, I.; Schoop, E.: Anforderungen an eine Tool-Unterstützung für Lehrende in virtuellen kollaborativen Lernsituationen - didaktische Normen und praktische Erfahrungen am Beispiel eines eCommerce Lernprojektes. In: Engelien, M.; Homann, J. (Edts.) Virtuelle Organisation und Neue Medien 2002. Workshop GeNeMe2002, Gemeinschaften in Neuen Medien. Josef Eul: Köln, 2002, pp. 189-217.

[BaSc04] Balázs, I.; Schoop, E.: Erfahrungen mit Virtual Collaborative Learning am Lehrstuhl Wirtschaftsinformatik insb. Informationsmanagement an der Technischen Universität Dresden. Band 1: Virtual Collaborative Learning: Ziele, Design, Erfahrungen. IMPULSEC Research Report 7, ISBN 3-936475-11-3, Osnabrück, 2004.

[Berg03] Bergan, S.: Entries and exits on the world stage: the Bologna Process and recognition of qualifications. In: Bergan, S. (Edt.) Recognition issues in the Bologna Process. Councel of Europe Publishing: Strasbourg, 2003, pp. 165-186.

[BoLa97] Bodendorf, F.; Langenbach, C.: Electronic Education Mall - Ein virtueller Marktplatz für mediengestützte Aus- und Weiterbildung. Wirtschaftsinformatik 39 (1997) 6: pp. 589-599.

[Bolo03] Bologna Declaration: The European Higher Education Area Joint Declaration of the European Ministers of Education convened in Bologna on the 19 June 1999. In: Bergan, S. (Edt.) Recognition issues in the Bologna Process. Councel of Europe Publishing: Strasbourg, 2003, pp. 241-243.

[Conk96] Conklin, E. J.: Capturing Organizational Memory. Group Decision Support Systems. http://www.touchstone.com/tr/wp/CapOrgMem.html, 1996, Download 200406-15.

[EC04] European Commission, Directorate-General for Education and Culture: eLearning Call for Proposals DG EAC/26/04. http://europa.eu.int/comm/education/programmes/ elearning/call_eac2604_en.html, 2004, Download 2004-06-28.

[Gron+03] Gronau, N.; Kern, E.-M.; Lukas, v. U.: Integration des Community-Gedankens in das Collaborative Engineering am Beispiel des Schiffbaus. In: Uhr, W.; Esswein, W.; Schoop, E. (Edts.) Wirtschaftsinformatik 2003 / Band II: Medien - Märkte - Mobilität. Physica: Heidelberg, 2003, pp. 21-40.

[Hein02] Heinrich, L. J.: Informationsmanagement. 7. Auflage, Oldenbourg: München, Wien, 2002.

[Kess00] Kessels, J. W. M.: Learning in Organisations: A Corporate Curriculum for the Knowledge Economy. http://www.kessels-smit.com/Publications/Learning_in_ organisations/learning_in_organisations.html, Kessels \& Smit, The Learning Company, 2000, Download 2004-04-15. 
[Klau+04] Klauser, F.; Schoop, E.; Wirth, K.; Jungmann, B.; Gersdorf, R.: The Construction of Complex Internet-Based Learning Environments in the field of Tension of Pedagogical and Technical Rationality. IMPULSEC Research Report 10, ISBN 3936475-15-6, Osnabrück, 2004.

[Mand+02] Mandl, H.; Gruber, H.; Renkl, A.: Situiertes Lernen in multimedialen Lernumgebungen. In: Issing, L. J.; Klimsa, P. (Edts.) Information und Lernen mit Multimedia und Internet. 3. Aufl. Beltz: Weinheim, 2002: pp. 139-150.

[Nuld99] Nulden, U.: e-ducation. Gothenburg Studies in Informatics, Report 14, May 1999, ISSN 1400-741X. www.handels.gu.se/epc/archive/00002535/01/Nulden.pdf, 1999, Download 2004-04-09.

[Payr03] Payr, S.: The Virtual University's Faculty: An Overview of Educational Agents. Applied Artificial Intelligence 17 (2003), pp. 1-19.

[Puls03] Pulst, E.: Interkulturelle Handlungskompetenz für Wirtschaftsinformatiker. In: Uhr, W.; Esswein, W.; Schoop, E. (Edts.) Wirtschaftsinformatik 2003 / Band II: Medien - Märkte - Mobilität. Physica: Heidelberg, 2003, pp. 601-618.

[Seuf00] Seufert, S.: The NetAcademy as a Medium for Learning Communities. Educational Technology \& Society vol. 3 (3), 2000, http://ifets.ieee.org/periodical/ vol_3_2000/a08.html, Download 2004-04-09. 